\title{
LIMITATION FOR SUSTAINABLE DEVELOPMENT OF THE REPUBLIC OF SERBIA
}

\author{
Dragana Milenković ${ }^{1}$ \\ University of Priština, Faculty of Economics Kosovska Mitrovica, Serbia \\ Ivan Milenković ${ }^{2}$ \\ University of Novi Sad, Faculty of Economics Subotica, Serbia
}

\begin{abstract}
In the first part of the paper we analyze core limiting factor for sustainable development in Serbia - delay of transition process, and unused experience of countries that had been in transition. Even one decade later, Serbia is not acknowledged postWashington consensus recommendations based on the experiences of some countries in Central and Eastern Europe. If sustainable development is understood as a country's ability to function in the given capacity, it is clear why in that second part of the paper we analyze the external imbalance of the Serbian economy. In the third part of the paper we analyze the recommendations for a new strategy of sustainable development. The economic development today is based on three sectors: financial intermediation, retail and wholesale trade, transportation, and telecommunications - that belong to nonexchangeable sector of the economy. Serbia needs to strengthen exchangeable sector in order to have export-stimulated growth instead of demand-stimulated growth.

Keywords: corporate managing, privatization, export structure, sector of exchangable and non-exchangable goods, foreign debt.
\end{abstract}

\section{INTRODUCTORY REMARKS AND LITERATURE REVIEW}

Economic growth model's proposed by Harward economists Roderick and Hausman (2008) starting point is relatively simple diagnostic framework for defining and overcoming key development limitations. On the one hand low yield in real economy reasons are observed (such as: infrastructure and workforce quality, market imperfections and state intervention). On the other hand, attention is on causes of high costs of financing, both from domestic and foreign sources. In utilization of such approach main responsibility lays on experts and decision-makers, who need to have deep understanding of theory in practice in order to valuate both public and hidden information to be able to define real economic growth limitation. Application of aforementioned model of growth diagnostics to Serbia would for sure reveal following results: cost non-effective, and massive role of the state in economy that create inefficient and expensive and non-competitive business environment. In addition, unit workforce costs are high, i.e. low productivity make obstacles to foreign direct inflows and erode firms'

\footnotetext{
1 e-mail: dragana.milenkovic@pr.ac.rs

2 e-mail: imilenkovic@ef.uns.ac.rs
}

Vol. 17, бpoj 1/2015, cmp. 13-24 
price competitiveness. High level of Serbian current account, as a consequence of high deficit in foreign trade witnesses that aggregate consumption in Serbia is mainly covered by import, rather than by domestic production. Since it is more and more difficult to get sources for financing abroad, limited availability of loans and huge costs of financing becoming main limitations for Serbian economic growth, which is this paper hypothesis. Aforementioned limitation requires brand new strategy of sustainable development if the Republic of Serbia, which is discussed in the third chapter of this paper.

Following Lay (1998, p. 35, cited: Cimlesa, 2010, p. 15) sustainable development is a process of improving human life quality, that takes place in a scope of available capacity sustainable eco-systems. If we do not living in a scope of available eco-system capacity - we are not sustainable for future generation neither for our generation, nor for ourselves. It is under question mark how to provide sustainable development, and improve quality of living preserving available capacities.

\section{INEFFICIENT CORPORATE MANAGEMENT AS A KEY LIMITATING FACTOR OF THE SUSTAINABLE DEVELOPMENT IN THE REPUBLIC OF SERBIA}

In 2001 in Serbia/FR Yugoslavia was adopted a strategy similar to other transition countries in Central-Eastern Europe, although a decade later, based on the neo-liberal model. A key role was given to liberalization, macroeconomic stabilization and privatization, provided in accordance with the recommendations of the so-called "Washington" consensus. Lessons from "Post-Washington" consensus, based on the experience of some Central-Eastern European countries after decades of transition, are not carefully taken into account. Adequate conditions to create and prosperity of newly formed private enterprises should be highlighted not only privatization of existing ones; importance of corporate management efficient system should be emphisised, not only privatization-driven ownership structure; importance of active competition policy that happened to be even more important than privatization itself; importance of active state's role, not only the role of the capital market; and finally, negative implications of too-restrictive both monetary, and fiscal policy (Kolodko G.W. \& Nuti, D.M., 1997, cited by: Uvalić, 2011, in Bajec \& Jaksic (Red.), 2011, p. 63). Serbia is neither a country in transition or post-transition, it is a country in transitionalism (Djuricin, 2008). There are many consequences of the transition that is taking too long. The two most important are: (a) the 
transitional recession (a dramatic fall in economic activity and inflation) and (b) low competitiveness. Another local economic crisis caused by an incomplete transition has led to increased risk of exposure to Serbia vis-avis the global economic crisis. Serbian economy, in fact, is in the combined crisis, transitional crisis and the global economic crisis that reinforce each other. When the economy reaches a pre-transition GDP level, the transition will be completed. Then begins the catch-up process to reach developed capitalist countries level of development. Consequently, the typical transition curve has the J-letter shape. In the case of Serbia, the double transition J-curve never reaches its pretransition level. At the end of 2009 Serbian GDP was 69\% of the pretransition level of 1989 The global economic crisis that began in 2008 launched the third J-curve cycle, pushing Serbia to the third strategic turning point (Djuricin \& Vuksanovic, 2010, p. 23).

Complex, as it is, transition process have to contain all dimensions of economic, social, political, judical, and socio-economic repositioning of the society in all its levels. To overcome such conditions are longlasting process, where innovativeness forces and entrepreneurs have major roles, able to take a chance of broad resistance and failures, in order to achieve necessary social changes and modernization. Entrepreneurial economy and entrepreneurship development could be an appropriate answer on transition crises, as well as economic crisis in Serbia (Grahovac, V., Karavidic, S. \& Cukanovic Karavidic, M., 2012, pp. 117118).

The importance of corporate governance, not just a change of ownership through privatization; importance of adequate conditions for the establishment and growth of new firms, not just the privatization of existing ones; the importance of active policy intervention that proved to be even more important for improving efficiency of privatization of firms. The share of the state sector in the formation of Serbia's GDP is still relatively significant and is estimated to be about $40 \%$. It is necessary to improve corporate governance as a key step needed to raise the competitiveness of enterprises in which are partially owned by the state. These companies need to be able to provide better services, to be more efficient, and able to compete internationally.

State sector participation in overall GDP in Serbia is still relatively high; it is estimated to be as high as 40\% of GDP. According to Serbian National Bank data, as of the beginning of 2012 there were 716 state-owned companies. As in any state in the world, Serbian Government should stay out of influencing economy. Rather than that it should create favorable institutional framework. When acting as the owner, the Government often acts opposite to good practice of corporate governance. 
The biggest issues and challenges which public enterprises face in Serbia are as follows (Eric, Stosic, Redzepagic, 2001, p. 4-5):

- Extremely high political influence - relating to the election of members of administrative and executive bodies. On the other hand, this results in very weak corporate governance, no disclosure, sometimes no transparency;

- Very low effectiveness and efficiency - as a result of poor management and in many cases total lack of leadership. PEs in Serbia are seen as "prey" gained by political parties after the elections, and leadership positions are often given to the obedient, and not capable human resources;

- Extremely poor financial results - many years of unprofitable operations of the five large public enterprises - Electric Power Industry of Serbia (EPS), Serbian Railways, Yugoslav Airways JAT, PEU Resavica and Roads of Serbia have not improved for years(...) Losses in this sector of the Serbian economy are socialized, i.e. ultimately paid by tax payers;

- The financial imbalance - Public companies are operating in insolvency (below-average quality and low liquidity ratios) and debt;

- Big possible sources of corruption - especially in the field of Public Procurement;

- Excess in the number of employees and inadequate qualification and age structure;

- Above-average salaries - constantly higher net earnings of public companies compared to the average earnings in the Republic of Serbia,

- Limited use of Public-Private Partnership (PPP).

The corporate governance framework should promote transparent and efficient markets, be consistent with the rule of law and clearly articulate the division of responsibilities among different supervisory, regulatory and enforcement authorities. Main principles of efficient corporate governance, according to the $\operatorname{OECD}(2004$, p. 29-31) are:

- The corporate governance framework should be developed with a view to its impact on overall economic performance, market integrity and the incentives it creates for market participants and the promotion of transparent and efficient markets. (p. 30)

- The legal and regulatory requirements that affect corporate governance practices in a jurisdiction should be consistent with the rule of law, transparent and enforceable. (p. 30) 
- The division of responsibilities among different authorities in a jurisdiction should be clearly articulated and ensure that the public interest is served.

- Supervisory, regulatory and enforcement authorities should have the authority, integrity and resources to fulfil their duties in a professional and objective manner. Moreover, their rulings should be timely, transparent and fully explained.

\section{EXTERNAL IMBALANCE OF SERBIAN ECONOMY}

Social development in the 20th century had been often identified with the economic development only, while other aspects of social development were neglected. Nevertheless since the 1950s, especially since the famous Club of Rome foundation, attempts of new theory economic development had been recorded. That theory integrated all elements that makes social development (economic, social and institutional). Sustainable development actually is development that meets present needs without endangering future generations from satisfying their needs.

The new era requires a new aproach to the economic development that would be based on real sources, primarily on saving and competitiveness. One that does not save and compete, shall not be successful in global economy. The savings rate in the USA after the Great Depression was over 30\%, while today it is less than 10\%. The Chinese savings rate is presently nearly $50 \%$. Isn't it one of the major causes of crash and prosperity of the USA and China? We can derive a similar conclusion by comparing their twin deficits (budget deficit and current account deficit). If we observe budget deficits only, USA's is $10.5 \%$ of the GDP, while China's is only $3.2 \%$ of the GDP, which is an incomprehensible gap between desires and possibilities; i.e., practice of the permanent predominance of consumption over production. Such practice became the rule both in market-based economies and in state intervention economies that undisputedly led to the crash of economic regime (Sukovic, 2011, in Bajec \& Jaksic (Ed. by), 2011, pp. 115-116).

Before the crisis outbreak, aggregate demand and inflation of assets; i.e., an investment-balloon situation that was inevitable to burst, had been associated with massive foreign trade deficit of many economies, especially that of the USA. (Sukovic, 2011, in Bajec \& Jaksic (Ed. by), 2011, p. 115) (see Table 1). Table 1 shows why China and other developing countries are less affected by the world economic crisis then that of America and Europe. But, speaking of other developing economies it should be borne in mind that they are less affected by crisis due to the 
fact that their financial sectors are not highly integrated in the global market. Therefore crisis effects were not intensively transmitted to their economies as to developing economies. This also applies to Serbia. Nevertheless, the financial crisis had negative effects on those economies too. This was due to both a decrease of foreign investments as well as due to a decrease of aggregate demand of developed economies. (Sukovic, 2011, in Bajec \& Jaksic (Ed. by), 2011, pp. 117-118)

Table 1.: Balance of current account (as a \% of world GDP)

\begin{tabular}{|l|l|l|l|l|l|l|l|}
\hline COUNTRIES & $\mathbf{1 9 9 9}$ & $\mathbf{2 0 0 1}$ & $\mathbf{2 0 0 3}$ & $\mathbf{2 0 0 5}$ & $\mathbf{2 0 0 7}$ & $\mathbf{2 0 0 9}$ & $\mathbf{2 0 1 0}$ \\
\hline USA & -0.96 & -1.21 & -1.41 & -1.62 & -1.33 & -0.72 & -0.71 \\
\hline EU & -0.04 & -0.08 & -0.05 & -0.03 & -0.19 & -0.37 & -0.33 \\
\hline China & 0.05 & 0.05 & 0.12 & 0.35 & 0.67 & 0.65 & 0.75 \\
\hline Japan & 0.37 & 0.28 & 0.37 & 0.37 & 0.38 & 0.17 & 0.17 \\
\hline Germany & -0.09 & 0.00 & 0.12 & 0.32 & 0.46 & 0.13 & 0.13 \\
\hline CIE & -0.7 & -0.3 & -0.08 & -0.12 & -0.22 & -0.11 & -0.09 \\
\hline Middle East & 0.05 & 0.13 & 0.15 & 0.45 & 0.46 & -0.02 & 0.10 \\
\hline $\begin{array}{l}\text { Middle Income } \\
\text { Countries }\end{array}$ & 0.05 & 0.05 & 0.12 & 0.35 & 0.67 & 0.65 & 0.75 \\
\hline
\end{tabular}

Source: IMF, World Economic Outlook, and author's calculations

Since the beginning of Serbia's economic transition, growth is relatively moderate. From 2000 until 2008 the average growth rate of the Serbian GDP is $5.4 \%$, which places Serbia into the leading position in comparison to other Central, Eastern and Southeastern European economies. Unfortunately, economic growth in that period had been unbalanced, and mainly based on just a few non-tradable sectors. In addition, economic growth in Serbia was also accompanied by a serious current account deficit, which proves that Serbian economy expenditures are way over its own resources. In the period of 2000-2008; i.e., until the outbreak of the world financial and economic crisis, the Serbian current account deficit was smoothly financed by surplus of the financial and capital accounts. Since the first quarter of 2009, it had been gradually much more difficult and more uncertain obtaining foreign sources of financing. Therefore the main focus is on attracting foreign investments as a source that does not require payback as is required by foreign loans. Investments in general should be directed by measures and instruments of monetary and fiscal policies toward more impactful industry sectors, and should be used to create much broader positive external effects. From the sustainable economic development's point of view, investments in general should be directed towards the so-called ,clean productive industries" (or "green industries"), and not to generators of so-called „gray technologies“. Being involved in development programs of 
transnational companies would positively change Serbian production structure from „low" and ,middle-low“ technology intensive industries industries that are technology intensive and rely on extracting natural resources, as it is today, toward advanced technology utilization.

Equilibrium model, where considerably faster growth of internal demand and consumption in comparison with GDP growth in Serbia, based on a large amount of foreign capital inflow will no longer be available (growth in domestic demand in 2008 was $7.5 \%$, while GDP rate was 5.4\%). Although Serbia's economic growth in recent years has been relatively high, it is primarily based on only three sectors (financial services, wholesale and retail trade, transportation, and telecommunications), which are responsible for about three-quarters of economic growth in the period 2002-2008. Three aforementioned sectors covers non-exchangeable part of the economy (their products mainly can not be exported), i.e. it rely primarily on the expansion of domestic demand. In near past demand growth was not accompanied by an appropriate expansion of production, especially in the sectors of exchangeable part of the economy. Therefore, the economic growth was accompanied by a relatively high trade deficit and current account deficit. A new model of economic growth will have to be in a much larger extent based on the non-exchangeable sectors of the economy. Foreign capital inflows, which in previous years were heavily funded domestic demand, due to global economic crisis will not be return to the previous volume when crisis finally finish. Also, the sectors that have so far been growth drivers, already reached a level that can be considered relatively high (about $15 \%$ per year), and their increase in the coming years will certainly be slower. As the rest of the economy in previous years grew at a relatively modest rate of $2 \%$ per year, it is necessary to increase the productivity of these sectors in the future.

Thus, economic growth in Serbia since the beginning of transition process was based on the expansion of domestic demand financed by high foreign capital inflows and strong growth of non-exchangeable sectors of the economy. Such increase in demand was accompanied by a corresponding expansion of the production and development of the real sector. However, this growth model is not sustainable in the medium term, at least for two reasons. Firstly, foreign capital inflows after the economic crisis and its severe downturn is unlikely to return to the previous level in the near future. Secondly, the sectors that have so far fueled through overall economic growth (financial services, wholesale and retail trade, transportation, and telecommunications) have already reached a relatively high level of participation in the GDP, and its further expansion in the future will certainly be slower than so far. All other 
sectors in the period 2002-2008 was rising at very modest rate rose (just over $2 \%$ per year). Logically, it is under question whether after the crisis will be any significant economic growth. The new growth model should relying to a much greater extent on tradable sectors of the economy, i.e. the sectors that export its products and services (or directly compete with imported products and services in the domestic market).

\section{Graph 1.: Main foreign-trade macroeconomic indicatiors of Serbian} economy, 2000-2008

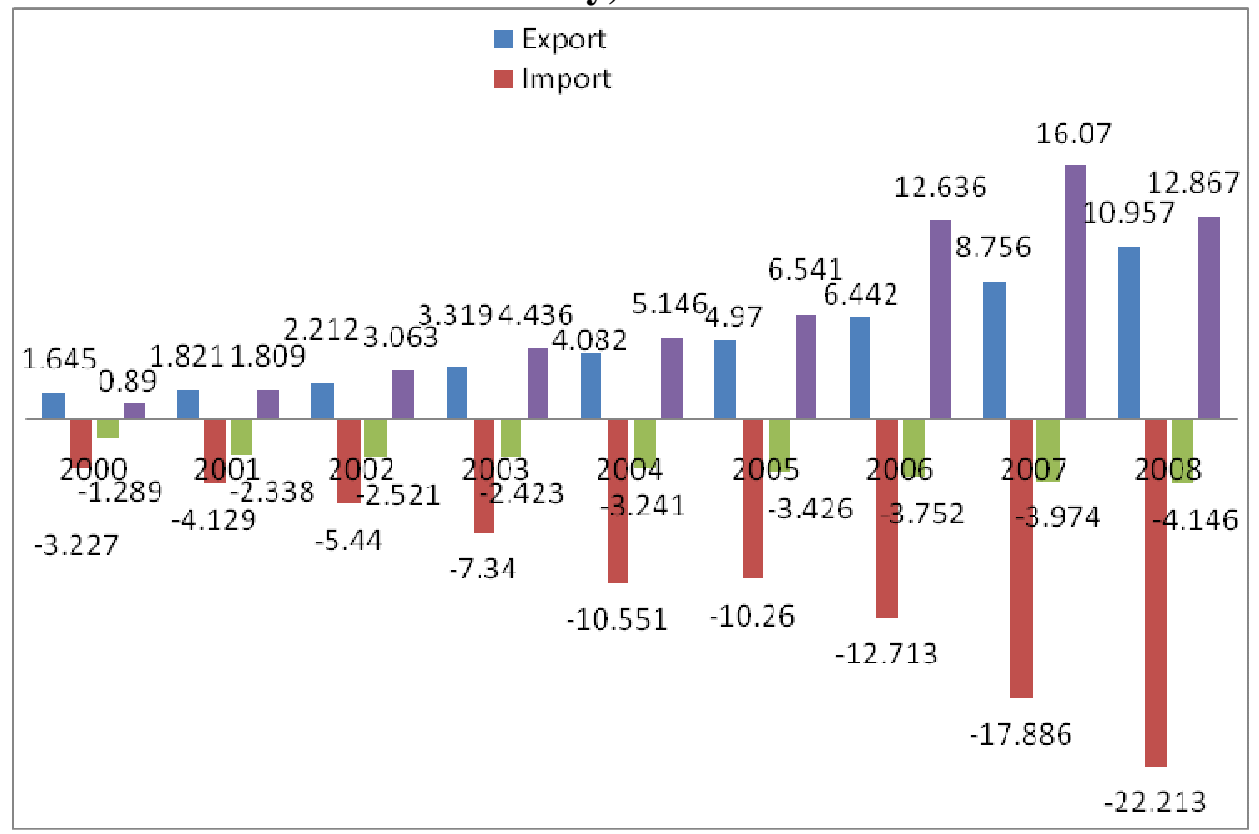

Source: National Bank of Serbia \& EBRD

\section{RECOMMENDATIONS FOR A NEW DEVELOPMENT STRATEGY}

One of the possible interpretations of sustainable development is that the essence of the concept of preserving different types of capital (economic, ecological and sociological) for present and future generations. The concept of the "weak" sustainability allows the possibility of capital substitution under terms that overall capital quantity remains. This means that environmental degradation costs could be compensated by economic capital creation. Therefore this concept of socalled "weak" role of sustainability does not negate environmental aspects, but assumes its monetary valuation. Regarding this issue, Serbia does not satisfy "weak" sustainability, not to mention "strong" sustainability principle, according to which it should support itself on 
dividends on available resources. The fulfillment of the principle of "strong" sustainability means that future generations should be able to live lives as quality as the present generation. Both Serbian sustainable production and consumption are not as developed as should be. Production structure of Serbian economy, that also define its export structure, is consisted mainly of agriculture product (grains, fruit and vegetable), low-skilled products and low-technology products. Energy efficiency in Serbia is at the very low level, although Serbia has energy deficiency. It implies both low national competitiveness, as well as environmental pollution accompanied with energy waste.

Serbian transition model of economic development shows that Serbia did not use enough examples of transition economies that finished their transition process by accession to the European Union. Former Central-European socialistic countries had started their transition to market economy in relative abundance of agriculture land, row-materials and both qualified and non-qualified workforce. Another heritage of socialistic period in aforementioned economies was an obsolete technology. According to Heckscher-Ohlin-Samuelson theory of exchange of goods, it was expected that labor-intensive products and natural resources-intensive products would be predominant in their exports. However, one research paper (Zaghini, 2003) proved opposite. According to this research labor-intensive products and natural resourcesintensive products were predominant only in early transition phase. Central-European post-transition economies' exports are mainly based on industrial products, and a few high-tech products. Appropriate strategy of attracting inward foreign direct investments, and positive heritage of centrally-planned economies (highly educated and skilled workforce) influenced positive export-structure upheaval of aforementioned CentralEuropean economies. Inward foreign direct investment flows are much more than simple capital inflow to the national economy: it also includes technology transfer and management practice. The New Serbian development strategy should be oriented toward the attracting inward foreign investments into the exchangeable sectors. In such way Serbian economy would generate more dynamic economic growth that would be export-driven (instead of demand-driven). The new Strategy of sustainable development of Serbia, which should be adopted in near future, should be grounded on knowledge-based economy. Serbia should follow positive experiences of knowledge based small and open economies - nations up to ten million inhabitants with GDP/capita of approximately USD 5,000 with export/GDP share of 50\%.

Begovic and authors (2008) states as good examples cases of the Republic of Ireland and Portugal. The main differences between those 
two economies are in salary policy and in policy of attracting foreign capital inflow. Massive inflow of foreign capital to the sector of processing industry in the Republic of Ireland contributed to the higher rate of growth in the sector of tradable goods, to export expansion and to the fast growth of factor productivity. As salaries lagged behind productivity, real effective exchange rates based on the unit costs of labor fell sharply, increasing profitability of the exporting sector and causing massive cost savings in the economy. Savings rose more than investments, and current account balance turned from deficit into surplus. The case of Portugal was different: massive foreign capital inflows mainly in the non-tradable sector, and much less to the processing industry - caused expansion of aggregate domestic demand and expansion of import. As stated, Ireland and Portugal had different models of economic development triggered by inflow of foreign capital. Ireland's model was based on expansion of supply (mainly through tradable sector), while Portugal's model was based on expansion of demand (mainly through non-tradable sector). The rate of salary increase overcame productivity increase and negatively affected the exporting sector. When the inflow of capital stopped in 2001, Portugal found itself trapped into a long-term high current account deficit and appreciated national currency. The processing industry was not competitive enough to reignite economic growth, and with the membership in the eurozone adjusting the exchange rate of national currency was no longer possible. Unfortunately, economic performances of Serbia are more similar to Portugal than Ireland (Begovic B. and authors, 2008, pp. 28-29).

At this moment Serbian coefficient of export concentration is at the low level due to exporting large number of low-market-share products. Therefore export concentration is low, but not due to high and diversified export level (as it is the case with developed economies), but due to exporting many different products of small export amount. CentralEuropean post-transition economies' experience proves that higher inward foreign direct investments are - lower coefficient of export concentration level is, which is the way Serbian export-orientation should take. The factor that contributes to poor results of Serbian economy is enormous and non-efficient state consumption, as well as poor redistribution of income, that was not aimed to create better conditions for economic growth. With aforementioned weakness, Serbia was not able to generate more dynamic economic growth that would be export-driven (instead of demand-driven). Expectations that the status of the EUcandidate member would attract inward foreign investments had not been fulfilled. Serbia was facing capital outflow, a deep recession, and combined - triple fiscal-debt-financial crisis. 


\section{CONCLUSION}

Our brief analysis emphasize following recommendations:

- Serbian transition model of economic development shows that Serbia did not use enough examples of transition economies that finished their transition process by accession to the European Union.

- The New Development strategy in Serbia should be related to knowledge-oriented economy, as a long-term goal.

- Main limiting factors of more advanced economic development in Serbia are structural weaknesses of its economy are: (1) late start of transition, as well as not using, as a role model, the experiences of most advanced economies of Central and Southeastern Europe that finished their transition process; (2) inadequate model of economic growth that is based on external deficit, i.e. on morethan-average growth of non-exchangeable goods and services sector. Exchangeable sector industries were too weak and not reformed enough to be internationally competitive and increase export.

\section{LITERATURE}

1. Bajec, J. \& Jaksic. M. (Ed. by)(2011). Nova strategija razvoja privrede Srbije - izazovi ekonomske politike u 2011. godini, NDE sa AEN i Ekonomski fakultet u Beogradu, Begrade.

2. Begovic B. \& authors (2008). Grinfild strane direktne investicije u Srbiji. Centar za liberalno-demokratske studije, Beograd.

3. Cimlesa, D. (2010), Ekoloski otisak - kako je razvoj zgazio odrzivost. Tim press, Zagreb.

4. Djuricin, D. (2008): Serbia: from tranzition to transitionism and back, Ekonomika preduzeca, Sept-Oct, 155-170.

5. Djuricin, D. \& Vuksanović, I. (2010). Predlozi za prevazilaženje negativnih posledica ekonomske krize u Srbiji, Proceeding from the conference, Banja Vrućica, 17-18.06.2010.

6. Dragicevic Radicevic, T., Mitrovic, R. \& Mikuljevic, M., (2012). Participativno odlucivanje i korporativno izvestavanje u kreiranju novih okvira korporativnog upravljanja, Megatrend Review, 4/2012, 185-199.

7. Eric, D., Stosic, I. \& Redzepagic, S. (2011). Restructuring of public enterprises as source of increasing competitiveness in Serbia and South-Eastern Europe region, proceedings from the conference. 
8. Grahovac, V., Karavidic, S. \& Cukanovic Karavidic, M. (2012). Preduzetnicka ekonomija u uslovima tranzicionog procesa, Megatred Review, 4/2012, 111-127.

9. Kolodko G.W. \& Nuti, D.M. (1997). The Polish alternative - Old myths, hard facts and new strategies in the successful Polish economic transformation, UNU WIDER Research for action Series, 33, cited: Uvalić M. (2011). Problemi dosadasnjeg modela razvoja Srbije, in Bajec J. \& Jaksic M. (Red.), Nova strategija razvoja privrede Srbije - Izazovi ekonomske politike u 2011. godini, NDE sa AEN i Ekonomski fakultet u Beogradu, Belgrade.

10. Milenkovic, I. \& Milenkovic, D. (2012). Inward foreign direct investments to Serbia - investigating motives in the past and prospects for the future, Review of Applied Socio- Economic Research, Volume 4, Issue 2/2012.

11. OECD (2004). OECD Principles of Corporate Governance, Paris, $1-67$.

12. Uvalic, M. (2012). Tranzicija u Srbiji, ka boljoj budućnosti, Zavod za udzbenike, Belgrade.

13. Uvalic M. (2011). Problemi dosadasnjeg modela razvoja Srbije, in Bajec J. \& Jaksic M. (Red.), Nova strategija razvoja privrede Srbije - Izazovi ekonomske politike u 2011. godini, NDE sa AEN i Ekonomski fakultet u Beogradu, Belgrade.

14. Zaghini, A. (2003). Trade advantages and specialization dynamics in acceding countried, Working Paper No. 249, European Central Bank, Frankfurt am Main. 